\title{
Introduction
}

\section{FEDERALISM, RECONCILIATION, AND POWER-SHARING IN POST-CONFLICT SOCIETIES}

\section{by Neophytos Loizides*, losif Kovras** and Kathleen Ireton ${ }^{* * *}$}

\footnotetext{
* School of Politics, International Studies and Philosophy, University of Belfast, UK Email: n.loizides@qub.ac.uk

** School of Politics, International Studies and Philosophy, University of Belfast, UK Email: ikovras01@qub.ac.uk

*** School of Politics, International Studies and Philosophy, University of Belfast, UK Email: sireton01@qub.ac.uk
}

\begin{abstract}
This special issue examines the interplay between reconciliation in postconflict societies and alternative mechanisms of political accommodation. In our introductory article, we define and explore the central concepts used in post-conflict studies while investigating the potential linkages between reconciliation and federal or power-sharing arrangements. We argue that addressing issues of justice, reconciliation and amnesty in the aftermath of conflict frequently facilitates cooperation in establishing successful institutional mechanisms at the political level. We also examine the degree to which reconciliation at the grassroots level should be seen as a prerequisite of consolidating power-sharing arrangements among elites particularly in the form of federal agreements. Finally, we discuss the individual contributions to the special issue and highlight the importance of incorporating insights from the literature of transitional justice and post-conflict reconciliation to the study and practice of federalism.
\end{abstract}

Keywords: federalism, linkage politics, reconciliation, power-sharing

Acknowledgements: Dr. Nicos Trimikliniotis shared many insightful ideas with us on federalism and reconciliation. Bruce Clark helped us shaped our arguments and kindly presented some of our work to the Economist audience. Dr Elizabeth Thompson edited our introductory chapter and colleagues at Queen's University Belfast assisted us with ideas and comments. 


\section{About Federal Governance}

Federal Governance is an online graduate journal on theory and politics of federalism and multilevel governance. Its mandate is to engage the global federalism community and reach out to outstanding graduate students interested in federalism and multi-level governance. By providing a platform for graduate students to have early success in their careers, Federal Governance seeks to promote and sustain interest in federalism and multi-level governance research among graduate students. Allied with the Forum of Federations and founding partner, Institute of Intergovernmental Relations at Queen's University; Federal Governance aims to contribute to a global dialogue on federalism.

Co Chairs, Advisory Committee:

Publisher:

Managing Editor:

Associate Editors:
Rupak Chattopadhyay and Christian Leuprecht

Forum of Federations

(Rupak Chattopadhyay and Rod Macdonell)

Annegret Eppler

Joshua Cerovski, Dominic Heinz,

Eva-Maria Maggi and Victoria Tait

\section{Terms of Use}

Your use of this Federal Governance article indicates your acceptance of Federal Governance's Terms and Conditions of Use, available at www.federalgovernance.ca/terms. Federal Governance's Terms and Conditions of Use provides that you may use Federal Governance content only for personal, academic and non-commercial use. Each copy of any part of this Federal Governance article must contain the same copyright notice that appears on the screen or printed page of such transmission. 


\section{Introduction}

On July 15, 2010, British Prime Minister David Cameron issued an unambiguous apology to the relatives and victims of the tragic events remembered in Northern Ireland and around the world as Bloody Sunday. Briefly stated, on January 30, 1972, 13 civilians died and more were wounded when the British Army opened fire on civil rights marchers in the Bogside area of Derry/Londonderry. More than three decades later, an inquiry conducted by Lord Saville established that the victims were unarmed and that soldiers fired without warning, even targeting fleeing civilians and others attempting to help the wounded or dying. Commenting on the report, Cameron said he was 'deeply sorry' and described what happened on Bloody Sunday as unjustified and unjustifiable (BBC 2010). This apology by a newly-elected Conservative UK Prime Minister was well-received by the victims and the Irish Nationalist community in Northern Ireland.

By the time of the apology, however, the province had already experienced a decade of relative stability and prosperity after the 1998 signing of the Belfast (Good Friday) agreement. As in comparable peace processes, the core of the Good Friday agreement stipulated that majority Ulster Unionists and minority Irish Nationalists should share power in well-defined consociational arrangements at the provincial level, run their own affairs at the community level where possible, and receive amnesty for violent actions committed by paramilitary groups (McGarry \& O'Leary 2004). But here, as elsewhere, the key question is how exactly do institutional mechanisms of accommodation such as federalism and consociationalism relate to issues of justice, reconciliation and amnesty? Despite the flourishing literature in both areas, little has been done to connect these two major challenges of post-conflict societies. Drawing from a diverse set of cases from North America, Western Europe, the Middle East, Sub-Saharan Africa, the former Soviet Union and South Asia, this special issue begins to address this omission. To this end, we consider whether justice and truth recovery are beneficial for the early stages of federal and consociational agreements or if justice should be delayed until conditions on the ground stabilize. More broadly, we look at the complex interplay between institutional incentives for intra-communal cooperation and justice initiatives - or the delay of these initiatives in post-conflict situations. The collection of articles herein shows a diversity of responses to comparable dilemmas.

Our introduction clarifies the most important terms used in the study of federalism, reconciliation, and power-sharing, underlines potential linkages in related studies in post-conflict societies, and provides a short outline of the key findings of each article. 


\section{Consociationalism and Federalism}

Discussions of institutional mechanisms of accommodating ethnic and national diversity often take place without distinguishing between two interrelated concepts: consociationalism and federalism (Lijphart 1979). Consociationalism (or powersharing), among other things, requires that power be shared by majorities and minorities, and it implies formal or informal veto rights for all parties (Lijphart 1977, 1979; McGarry \& O'Leary 1993). Federalism refers to situations where authority is divided between central and provincial governments, with both enjoying constitutionally separate competencies (O'Leary 2001: 49-52). Federations can be consociations, as in Belgium and Switzerland, but not all federations are consociations, as in the United States and Australia, or semi-consociations, as in Canada and India (Lijphart 1977: 513). There are also consociational agreements with territorially intermingled populations that do not take a federal form, such as post-1960 Cyprus, Lebanon, and Northern Ireland after the 1998 Good Friday Agreement (O'Leary 2001:44).

About 40 percent of world's population live in countries that can be considered as, or claim to be, federal (Watts 2002), and the global spread of federal and consociational arrangements has triggered a burgeoning literature across disciplines, including critical views of federal arrangements following the collapse of the former Soviet Union and Yugoslavia. Federal systems, however, have demonstrated a high level of stability; almost no federation has failed within the European Union or among post-WWII industrial democracies (Bermeo 2002; McGarry \& O'Leary 2009). Agreements which include ethnic federal units are more stable and functional, as each national community runs its own domestic affairs, ranging from road infrastructure to health and social welfare.

This does not imply that federalism lacks problems, as suggested by several cases of collapse in the former Soviet bloc (see the chapter by Barker), or in developing countries (see Kenning's chapter), not to mention Belgium, a situation which is problematic but relatively stable. Ceteris paribus societies that have experienced collapse in power-sharing agreements tend to hesitate before re-adopting federal or consociational arrangements. But as we argue here, federalism and power-sharing are often the only possible choices for deeply divided societies. In general, peace processes require difficult trade-offs between undesirable but unequal alternatives. Federalism and power-sharing might appear problematic, but partition and de facto stalemates are even more so (see Suzuki's chapter).

Moreover, critics of federal and consociational arrangements in post-conflict societies often point to their 'undemocratic nature' particularly their divergence from the principle of one person one vote (for a response to these arguments see Moore's article). Yet this view is questionable, as weighted voting systems are neither new nor particularly exceptional (Loizides, 2010). Democracy emphasizes equal representation of every individual, that is, one person one vote, whereas federalism guarantees equal 
representation of member-states of a federation, that is, an equal vote for every state in at least a number of areas (Linder, 1994: 73). Thus in Switzerland, 9\% of the Swiss population (residing in the smallest cantons) could block a democratic majority of $91 \%$ (ibid) while in the US, the difference in a Senate vote between the smallest and largest states can reach a ratio of 1 to 50 or more. As mentioned earlier, about 40 per cent of the world's population lives in democratic or democratizing federations. By their very nature, federal systems try to balance individual rights with those of the governing federal units, drawing on weighted voting systems to do so. In mature democracies such 'electoral anomalies' are often accepted and gradually become almost completely normalized in the public eye (Economist, 2011).However, as the Moore article implies their capacity to polarize debates among non-reconciled post-conflict communities should not be underestimated.

Furthermore, consociational agreements which demand common decision-making in most areas of daily public life, even overlapping minority and majority vetoes, are usually less functional than federal arrangements without formal power-sharing. Critics have emphasized the 'undemocratic and dysfunctional character' of such arrangements. This special issue reviews these arguments by providing countryspecific assessments of a variety of situations. For the most part, consociationalism involves guaranteed group representation. Elites come together to rule in the interests of society because they recognize the dangers of non-cooperation (Lijphart 2004). Because it focuses on elite bargaining and mutual vetoes, critics have argued that consociationalism prevents the development of a stable culture of compromise at the grassroots level. Parties become more antagonistic, they say, leading to public alienation from the peace process.

Critics also suggest incentives for cross-ethnic moderation, including electoral mechanisms allowing members of one ethnic community to vote for the other community's representatives, along with voting for their own community (Horowitz 1991, 1993). Electoral engineering is not without risks, however. For one thing, despite positive intentions, political parties might lose control of voters in moments critical for a peace agreement; for another, incentives for electoral moderation might backfire among the public, if the latter demands the 'genuine' representation of its own ethnic community (Loizides \& Keskiner 2004; McGarry \& O'Leary 2009).

These critiques are particularly relevant in cases where institutional mechanisms of grassroots cooperation occur in the absence of genuine reconciliation initiatives. One cannot conclude that moderation will result exclusively from institutional mechanisms without addressing issues of justice, reconciliation, and amnesty. More specifically, the efficacy of electoral and consociational arrangements is highly dependent on the state of ethnic relations. This calls for greater emphasis on issues of justice and community reconciliation which affect the decision by elites and ordinary citizens alike to cooperate in power-sharing and federal agreements. 


\section{Reconciliation and Apology}

Until recently, the majority of peace settlements and transitions to democracy especially when these were the product of a mutual stalemate - were founded on some form of amnesty (Vinjamuri \& Boesenecker 2006). In such a situation, societies could choose to bury their past. This trend has radically changed since the early 1990s, when a 'normative turn' began to inform the priorities of the international community, making reconciliation, transitional justice, apologies, and more generally, a moral scrutiny of the past tenets of the transition process. This 'turn' can be attributed to two developments. The changing texture of violence in civil wars, involving not only regular soldiers but irregulars/civilians, often results in massive civilian casualties. Therefore, in the aftermath of the cessation of hostilities, the objective is no longer merely 'negative peace' - or the absence of violence - but 'social transformation' that will eventually restore broken social bonds and reinstate collapsed institutions (Hamber 2003:155). In this dual normative context, the concept of reconciliation is a central goal of peacebuilding.

Despite growing academic and political attention, the concept of reconciliation is as yet inadequately explored. For one thing, there is no agreed-upon definition. For his part, John Paul Lederach focuses on 'building relationships between antagonists', arguing that the primary objective of reconciliation is to 'address, integrate and embrace the painful past and the necessary shared future as a means of dealing with the past' (Lederach 1997:31). Luc Huyse provides a similar definition: 'Reconciliation prevents, once and for all, the use of the past as the seed of a new conflict. It consolidates peace, breaks the cycle of violence and strengthens newly established democratic institutions' (Huyse 2005:8). Arguably the most frequently cited definition of reconciliation comes from the Institute for Democracy and Electoral Assistance (IDEA) who assumes that 'reconciliation is an overarching process that includes the key instruments of justice, truth, healing, and reparation for moving from a divided past to a shared future' (IDEA 2003:4).

So too, the central analytical concepts of reconciliation are vague and lead to a number of inter-related questions. Is reconciliation an objective (end-goal) or a process (means to an end)? Who are the actors to be reconciled? Does reconciliation refer to individual reconciliation (victim and perpetrator) or national/societal reconciliation? The absence of analytical rigour can be attributed to the tendency of scholars to highlight the need for transitional justice/reconciliation mechanisms. This 'faith-based' approach has focused on describing 'success stories' (Thoms et al. 2008), leaving unexplored other analytical concepts and important policy areas. For example, the literature has abstained from designing a holistic strategy of reconciliation that could smoothly incorporate reconciliation into strategies of economic reconstruction-development, electoral engineering (see Moore's chapter), reform of education, etc. 
Scholars from different disciplines tend to investigate different aspects of reconciliation, focus on different actors, adopt different instruments, and ultimately subscribe to different definitions of reconciliation, thereby leading to what could be called a dialogue of the deaf. However, a very loose and generic categorization would identify four main clusters: the legal, political, theological, and political psychology approaches (for a tabular presentation, see Table I). Needless to say, this is a crude classification since some approaches may overlap on certain issues.

\begin{tabular}{|c|c|c|c|}
\hline Approaches & $\begin{array}{c}\text { Focus/Unit of } \\
\text { Analysis }\end{array}$ & Instruments & Objective \\
\hline Legal & $\begin{array}{c}\text { Individual } \\
\text { (Perpetrator) }\end{array}$ & $\begin{array}{c}\text { Retributive Justice } \\
\text { (Tribunals; Policies } \\
\text { of Lustration) }\end{array}$ & $\begin{array}{c}\text { Reconciliation } \\
\text { (deterrence and } \\
\text { Rule of Law) }\end{array}$ \\
\hline Political & Society & Amnesties & $\begin{array}{c}\text { Reconciliation } \\
\text { (democratic } \\
\text { consolidation) }\end{array}$ \\
\hline Theological & $\begin{array}{c}\text { Individuals (victim } \\
\text { and perpetrator) and } \\
\text { Society }\end{array}$ & $\begin{array}{c}\text { Restorative Justice } \\
\text { (Forgiveness; } \\
\text { grassroots activities - } \\
\text { Ubuntu; Gacaca; } \\
\text { Truth Commissions) } \\
\text { Political Psychology }\end{array}$ & $\begin{array}{c}\text { Reconciliation } \\
\text { (restoration of } \\
\text { broken social } \\
\text { relations) }\end{array}$ \\
Collective/ National \\
identities & $\begin{array}{c}\text { Truth Recovery } \\
\text { (Truth Commissions; } \\
\text { revised history } \\
\text { textbooks) }\end{array}$ & $\begin{array}{c}\text { Reconciliation } \\
\text { (reconstruction of } \\
\text { collective } \\
\text { identities) }\end{array}$ \\
\hline
\end{tabular}

Table I: Approaches to Reconciliation

The legal approach names the post-World War II Nuremberg trials as its legitimizing moment. Scholars subscribing to this 'logic of appropriateness' (Snyder \& Vinjamuri 2004) take the individual (perpetrator) as their unit of analysis; the approach argues that retributive justice will bring 'closure' to the victims and deter potential perpetrators from repeating the same atrocious acts in the future (Markel 1999; Mendez 2001; Neier 1999; Orentlicher 1991). An overlapping argument suggests that retributive measures implemented immediately after the transition educate the citizenry to the rule of law and thus contribute to reconciliation in the long term (Dyzenhaus 2000).

The objective of the political approach is the consolidation of the democratic regime which will provide the institutional framework required for national reconciliation. According to the 'logic of consequences' informing this approach, impunity should not be considered incompatible with reconciliation (Vinjamuri \& Snyder 2004). In fact, amnesties should be deployed if they have the potential to restore order and stability always necessary for democratic consolidation (Hesse \& Post 1999). Scholars subscribing to this logic underscore successful reconciliations in several societies which deployed amnesties during a 'third wave' of democratization, such as Spain. 
The theological approach has gained momentum in the aftermath of the South African Truth Commission and the application of the principles of 'Ubuntu'. It focuses on the restoration of broken (social and individual) relations (Elshtain 2003; Philpott 2006; Torrance 2006). In this view, the concepts of repentance, compensation, and contrition are central ingredients for reconciliation (Shriver 2003:35). 'Restorative justice' has become a core concept on the corresponding academic agenda because of its focus on 'restoring' broken relations.

Finally, political psychological perspectives identify the need to reconstruct collective/national identities in a more inclusive way in the aftermath of a conflict as a sine qua non precondition of reconciliation (Kelman 1999, Norval 1998, Rushton 2006). The recovery of truth is important not only because it creates a body of documentary evidence which prevents revisionist tendencies, but because it highlights the 'cathartic' function of truth (Hayner 1996, 2002). Revealing is healing (Minow 1998:326).

As a corollary to this, the role of apologies in reconciliation remains controversial, but when used correctly, they are believed to have a profound benefit. In post-conflict settings, political apologies have a healing effect on relationships by restoring moral balance and equality of regard (Taft 2000:1137). Conflicts often result in the dehumanization of groups or collectives within the greater society through violations of human rights, discrimination, violence, and other antagonistic acts which lead to distrust between communities. Coicaud and Jonsson (2008:90) say, 'For the same reason that dehumanization is the most powerful tool of war, humanization is the most powerful tool of reconciliation'. Re-humanization offers equality and an opportunity for unity between victim and perpetrator; it allows the repair of broken relationships and the creation of new ones. However, as Freeman (2008:57) notes, while apologies can promote humanization, they do not rectify wrongs on their own.

One of the most important aspects of an apology is its ability to renegotiate national identity and group membership (Nobels 2008:28) by promoting coexistence and civic trust (de Grieff 2008:124). This does not necessarily mean rewriting the past; rather, it can change how groups and their members stand in relation to their shared history. Such change is accomplished through power exchange and acknowledgement. An apology operationalizes guilt by creating a bridging dialogue and standardizing a way to deal with responsibility through public accountability (Barkan \& Karn 2006:24). In an exchange of power between the offender and the victim (Lazare 1995:42), the offender submits to self-punishment, while shame is removed from the victim.

Looking at the acknowledgement provided in apologies is a connected but slightly altered approach. Govier and Verwoerd (2002) argue that the offenders' acknowledgement of their offense explains the importance of an apology to victims and to reconciliation generally. Acknowledgement inspires a shift in attitude on both sides, and this enables the reconstruction of relationships (Howard-Hassman \& Gibney 
2008:4). Apologizing is also an act of 'acknowledgement of the authority... upon which social harmony is based' (Wagatsuma 1986:473).

Apologies are often used in lieu of, or in tandem with, judicial or legal justice. While the two are not exclusive, justice does not encapsulate the psychological healing that is an essential result of successful apologies. Rotberg (2006:47) argues that by focusing on retributive justice, we hinder reconciliation. Thus, apologies are a better means to address the rehabilitation of individuals and society, especially as they are easily accessed by those who have been hurt (Nobels 2008:30). As in the case of Bloody Sunday in Northern Ireland, however, there are fears in many legal jurisdictions that an apology could be (mis)used as an admission of guilt or liability, thereby demanding the involvement of judicial processes.

Actors can offer apologies for many reasons, not least of which is personal (or group) benefit. Apologies are often offered simply because it is the right thing to do, or because the perpetrator has changed his/her position on the appropriateness of certain behaviour. However, apologies are sometimes given to fulfill judicial decisions or because of coercion, and such apologies are not likely to be accepted in a process of reconciliation. Equally likely to be unsuccessful are apologies offered to diffuse tension, appease national sentiment through an act of public relations, or avoid unpleasant consequences (Bilder 2008:24-27).

Admittedly apologies can disagree with the facts, show a lack of respect, proffer a hidden agenda, spout exclusionary discourse, or focus too much on the past. However, they can also reveal the truth and set the record straight so that reconciliation can proceed. Apologies demonstrate that the offender believes he/she has transgressed and that he/she now has specific beliefs about the morally relevant aspects of his/her action which make it a transgression (Davis 2002:170).

In a best-case scenario, the healing power of an apology can remove the desire for revenge and generate forgiveness between the parties (Lazare 2004:1).

\section{Chapter Outline}

This special issue covers diverse situations from around the world, including Somalia, India-Pakistan, Cyprus, Spain, and Canada. Akisato Suzuki examines whether partition is preferable to federalism and consociationalism by comparing the historical cases of Cyprus and India-Pakistan. Gavin Moore considers the dilemmas of democratization in negotiating federalism and consociationalism, drawing on the Annan Plan in Cyprus and its implications for reconciliation. Ian Dunbar asks a similar question with respect to established federations in Canada and Spain, emphasizing the recent decision of the two societies to break prolonged silences and deal with a hurtful past. The final two essays by Christopher Barker and David Kenning question conventional wisdom in federalism studies by demonstrating how political accommodation can operate in 
difficult environment: the transition from communism in Tatarstan (Barker) and state collapse in sub-Saharan Africa (Kennning).

In his chapter, Akisato Suzuki critically examines the relationship between partition and reconciliation. The two cases under scrutiny, the partition of India and Pakistan (1947) and the de facto partition of Cyprus (1974) show that this instrument of conflict resolution may lead to conflict transformation but definitely not to comprehensive settlement. Kashmir has become a tinderbox which has flared up into several wars between India and Pakistan. Equally, the partition of Cyprus may have contributed to the absence of violence on the island, but it has poisoned the bi-lateral relations of its Aegean neighbours, Greece and Turkey. Since 1974, Greece and Turkey have considerably increased their military expenditures; in several instances, they were on the brink of war, making Cyprus an extremely flammable issue in the Eastern Mediterranean. Suzuki concludes that partition may transform the intrastate conflict into an interstate one, making the need for policies of reconciliation essential, even after negotiated partitions - a policy lesson with direct implications for the current negotiations in Israel/Palestine.

The 'normative turn' in international politics seems to have shaped the agenda not only for societies emerging from conflict but also for consolidated democracies. Ian Dunbar highlights the reasons why societies decide to defer the implementation of reconciliation policies even when the regime is consolidated. His chapter juxtaposes the experiences of two full-blown democracies, Canada and Spain, and their struggle to 'face the past'. More than 70 years after the conclusion of the Spanish civil war, the generation of the grandchildren of the defeated has initiated an unprecedented effort to recover the historical (republican) memory and acknowledge their suffering under Franco. Similarly, in Canada, a process of acknowledging the abuse of aboriginal people in Indian Residential Schools is underway. Dunbar concludes that 'advanced democracies are unlikely to avoid confronting the past', since 'the inherent principles of political contention and debate embedded within consolidated democracies make them particularly well-suited to withstand these potentially divisive processes'. His findings demonstrate the commonalities and the differences of advanced and emerging democracies in truth recovery.

Gavin Moore's contribution features a neglected aspect of the literature, namely the link between electoral engineering and reconciliation. The chapter critically evaluates the 'one-person one-vote' principle and its potential contribution to reconciliation. Contrary to the general perception that this principle is conducive to reconciliation since it is based on the democratic principle and as such could accommodate procedural fairness - Moore shows that this is only partly true. His coherent argumentation indicates that this principle can, under certain circumstances, be counterproductive. The 'one-person-one-vote' principle can relegate the status of minorities to 'junior partners'. Further, only minimal incentives are offered for 
participation in the nascent institutions, and this significantly undermines reconciliation initiatives. A study of the reunification plan for Cyprus (Annan Plan), illustrates that divergence from the 'one-person-one-vote' principle may be considered a credible alternative if it is inclusive, encourages minority participation, and has the potential to contribute to political accommodation/reconciliation.

The chapter by Christopher Barker turns to a model of cultural accommodation, based on ethnic federalism showing how Muslims and Christians in Tatarstan use cooperation and reciprocal religious tolerance to thwart potential conflicts. He notes that a history of third party oppression and Soviet anti-religious policy helped develop ties among Tatars and Orthodox Christians during the communist era. This has played into contemporary politics and is behind the inter-ethnic tolerance of Tatarstan. While Russia has often played the provocateur, Tatars and Christians have used flexibility, attitude, and autonomy, along with shared economic goals, to live in peace. For this reason, efforts to extend Tatar control of Tatarstan have been viewed positively. The relationship between Tatarstan and Russia is marked by cultural and religious tolerance, economic freedom, and sensitivity to differences, thereby providing an example to other sensitive Russian federal regions. By featuring this case study, the chapter questions conventional assumptions on the failure of federal systems in the former Soviet bloc.

Finally, David Kenning's chapter shows the practicality of allowing federalist systems to flourish in multi-ethnic regions in sub-Saharan Africa. Acknowledging the difficulties of the nation-within-a-nation dilemma, Kenning contrasts the experiences of Somalia and Somaliland to show how the two areas have achieved peace. A series of humanitarian interventions in Somalia and rigid attempts to implement a centralized democracy led to the failure of both the state and the international community to end the inter-clan militia struggle. In contrast, Somaliland has independently formed a federation based on traditional clan politics and has enjoyed extensive peace. As these case studies show, in non-ethnically homogeneous regions where clan rivalries are embedded in historical identity, a federal model of government provides greater equality of representation, addresses minority issues, and allows more regional specialization and civil society engagement than does a centralized democracy.

\section{Conclusion}

The articles included in this special issue provide insights from a wide variety of case studies. They address the multilevel links between federalism, consociational agreements, and reconciliation, highlighting the potential of federal and consociational solutions to catalyze social transformation, reconciliation, and peace-building. Central questions, only marginally explored by the relevant literature, including the fragile balance between the consociational or federal nascent state, electoral engineering, and 
the pursuit of justice and reconciliation, are highlighted. As the cases show, reconciliation and apologies are central policy considerations, even in established democracies, and they have an impact on bilateral state relations. It is our hope that the nuanced understanding offered here of the linkages between the institutional formation of the state and the growing demand for a (normative) re-evaluation of the past will update our readers' awareness of some key issues on the agenda of international politics. 


\section{References}

[1] Barkan, E. \& Alexander K. 2006, Taking Wrongs Seriously Stanford, CA: Stanford University Press

[2] Bermeo, N. 2002, "The Import of Institutions" Journal of Democracy, vol. 13, no. 2, pp. 96-110.

[3] Bilder, R. B. 2008, "The Role of Apology in International Law" in The Age of Apology: Facing up to the Past, eds. M. Gibney, R.E. Howard-Hassman, J.M. Coicaud \& N. Steiner, University of Pennsylvania Press, Philadelphia, pp.13-30.

[4] BBC June 15, 2010, "Bloody Sunday: PM David Cameron's full statement" retrieved from http://www.bbc.co.uk/news/10322295 [April 13, 2011].

[5] Coicaud, J. M. \& Jibecke J. 2008, "Element of a Road Map for a Politics of Apology" in The Age of Apology: Facing up to the Past, eds. M. Gibney, R.E. Howard-Hassman, J.M. Coicaud \& N. Steiner, University of Pennsylvania Press, Philadelphia, pp.77-92.

[6] Davis, P. 2002, “On Apologies”, Journal of Applied Philosophy, vol. 19, no. 2. pp. 169-173.

[7] de Greiff, P. 2008, "The Role of Apologies in National Reconciliation Processes: On Making Trustworthy Institutions Trusted" in The Age of Apology: Facing up to the Past, eds. M. Gibney, R.E. Howard-Hassman, J.M. Coicaud, N. Steiner, University of Pennsylvania Press, Philadelphia, pp.120-136.

[8] Dyzenhaus D. 2000, "Justifying the Truth and reconciliation Commission", The Journal of Political Philosophy, vol. 8, no. 4, pp. 470-496.

[9] Economist, 2011, Political Systems, The Fashion to be Federal, (February $24^{\text {th }}$ )

[10] Elshtain, B. J. 2003, "Politics and Forgiveness", in Burying the Past. Making Peace and Doing Justice after Civil Conflict, ed. N. Biggar, Georgetown University Press, Washington D.C., pp.45-62.

[11] Freeman, M. 2008, "Historical Injustice and Liberal Political Theory" in The Age of Apology: Facing up to the Past, eds. M. Gibney, R.E. Howard-Hassman, J.M. Coicaud, N. Steiner, University of Pennsylvania Press, Philadelphia, pp. 45-60.

[12] Govier, T. \& Verwoerd, W. 2002, "The Promise and Pitfalls of Apology", Journal of Social Philosophy, vol. 33, no 1, pp.67-82.

[13] Brandon, H. 2003, "Does the Truth Heal? A Psychological Perspective on Political Strategies for Dealing with the Legacy of Political Violence", in ed. N. Biggar Burying the Past. Making Peace and Doing Justice after Civil Conflict, Georgetown University Press, Washington D.C., pp.152-167.

[14] Hayner, P. 2002, Unspeakable Truths. Facing the Challenges of Truth Commissions, Routlege, London.

[15] Hayner, P. 1996, "Commissioning the Truth: Further Research Questions", Third World Quarterly, vol.17, no.1, pp. 19-22. 
[16] Hesse, C. and Pos, R. 1999, "Introduction”, Eds. Ibid. Human Rights in Political Transitions: Gettysburg to Bosnia, Zone Books, New York, pp. 13-38.

[17] Horowitz, D. 1991, A Democratic South Africa? Constitutional Engineering in a Divided Society, University of California Press, Berkeley.

[18] Horowitz, D. 1993, "The Challenge of Ethnic Conflict: Democracy in Divided Societies", Journal of Democracy, vol.4, no.4, pp. 18-38.

[19] Howard-Hassman, R. \& Gibney, M. 2008, "Introduction: Apologies in the West" The Age of Apology: Facing up to the Past, eds. M. Gibney, R.E. HowardHassman, J.M. Coicaud \& N. Steiner, University of Pennsylvania Press, Philadelphia, pp.1-12.

[20] Huyse, L. 2005, "Reconciliation: Theory and Practice", in eds G. Kelly and B. Hamber Reconciliation. Rhetoric or Relevant? Democratic Dialogue, Belfast, pp.7-13.

[21] International Institute for Democracy and Electoral Assistance (IDEA) 2003, "Reconciliation after Violent Conflict", retrieved from http://www.idea.int/publications/reconciliation/upload/reconciliation_full.pdf [April 13, 2010].

[22] Kelman, C. H. 1999, "Building a Sustainable Peace: The Limits of Pragmatism in the Israeli-Palestinian Negotiations", Peace and Conflict: Journal of Political Psychology, vol.5, no.2, pp. 101-115.

[23] Kovras, I. 2008, "Unearthing the Truth: The Politics of Exhumations in Cyprus and Spain", History and Anthropology, vol.19, vol.4, pp.371-390.

[24] Kovras, I.\& Loizides, N. 2011, "Delaying Truth Recovery for Missing Persons", Nations and Nationalism, vol. 16, no. 4 (forthcoming).

[25] Lazare, A. 1995, "Go Ahead, Say You're Sorry" Psychology Today, Jan/Feb, p. $40-43$.

[26] Lazare, A. 2004, On Apology, Oxford University Press, New York.

[27] Lederach J. P. 1997, "Building Peace. Sustainable Reconciliation in Divided Societies", Unites States Institute of Peace, Washington D.C.

[28] Lijphart, A. 1968, The Politics of Accommodation: Pluralism and Democracy in the Netherlands, University of California Press, Berkeley.

[29] Lijphart, A. 1977, Democracy in Plural Societies: A Comparative Exploration, Yale University Press, New Haven.

[30] Lijphart, A. 1979, "Consociation and Federation: Conceptual and Empirical Link", Canadian Journal of Political Science / Revue canadienne de science politique, vol. 12, no. 3, pp. 499-515.

[31] Lijphart, A. 2004, "Constitutional Design for Divided Societies", Journal of Democracy, vol. 15. no. 2, pp.96-109.

[32] Linder, W. 1994, Swiss Democracy: Possible Solutions to Conflict in Multicultural Societies, London: St. Martin's Press. 
[33] Loizides, N. \& and Keskiner, E. 2004, "The Aftermath of the Annan Plan Referendums: Cross-Voting Moderation for Cyprus" Southeast European Politics, vol 5, no. 2-3, pp. 158-171.

[34] Loizides, N. \& Antoniades, M. 2009, "Negotiating the Right of Return", Journal of Peace Research, vol. 46, no.5, pp. 611-622.

[35] Loizides, N. 2010, "The Cyprus Negotiations and "the one person-one vote principle": Examples of Divergence from Democratic Federations" (available at: http://works.bepress.com/neophytos_loizides)

[36] Markel, D. 1999, "The Justice of Amnesty? Towards a Theory of Retributivism in Recovering States", The University of Toronto Law Journal, vol.49, no.3, pp.389-445.

[37] McGarry, J. \& O'Leary, B. (eds.) 1993, The Politics of Ethnic Conflict Regulation, Routledge, London.

[38] McGarry, J. \& O'Leary, B. 2004, The Northern Ireland Conflict: Consociational Engagements, Oxford University Press, Oxford.

[39] McGarry, J. \& O'Leary, B. 2009, “Power Shared after the Deaths of Thousands", in ed. R. Taylor, Consociational Theory: McGarry and O'Leary and the Northern Ireland Conflict, Routledge, London, pp. 15-85,.

[40] Mendez, E. J. 2001, "National Reconciliation, Transnational Justice, and the International Criminal Court", Ethics and International Affairs, vol. 15, no.1, pp. 25-44.

[41] Minow Martha (1998) 'Between Vengeance and Forgiveness. South Africa's Truth and reconciliation Commission', Negotiation Journal, Vol.14 (4), pp. 319355.

[42] Neier Aryeh (1999) 'Rethinking Truth, Justice, and Guilt after Bosnia and Rwanda', in Carla Hesse and Robert Post (eds.), Human Rights in Political Transitions: Gettysburg to Bosnia, pp.39-51, New York, NY: Zone.

[43] Nobels, M. 2008, The Politics of Official Apologies, Cambridge University Press, New York.

[44] Norval J. A. 1998, "Memory, Identify and the (Im)Possibility of Reconciliation: The Work of the Truth and Reconciliation Commission", Constellations, vol.5, no.2, pp.50-265.

[45] O'Leary, B. 2001, "The Elements of Right-Sizing and Right-Peopling the State", eds B. O' Leary, I. Lustick, and T. Callaghy, Right-sizing the State: The Politics of Moving Borders, Oxford University Press, Oxford, pp.15-73.

[46] Orentlicher, D. 1991, "Settling Accounts: The Duty to Prosecute Human Rights Violations of a Prior Regime", The Yale Law Journal, vol.100, no.8, pp. 25372615.

[47] Philpott, D. 2006, "Beyond Politics as Usual. Is Reconciliation Compatible with Liberalism?" in The Politics of Past Evil. Religion, Reconciliation, and the Dilemmas of Transitional Justice, ed. D. Philpott, University of Notre Dame Press, Notre Dame, pp. 11-44. 
[48] Rotberg, R. I. 2006, "Apology, Truth Commissions, and Interstate Conflict" in Taking Wrongs Seriously: Apologies and Reconciliation, eds. E. Barkan \& A. Karn, Stanford University Press, Palo Alto, California, pp.33-49.

[49] Rushton B. 2006, "Truth and Reconciliation? The Experience of Truth Commissions", Australian Journal of International Affairs, vol. 60, no. 1, pp. 125141.

[50] Taft, L. 2000, "Apology Subverted: The Commodification of Apology", The Yale Law Journal, vol. 109, no. 5, p.1135-1160.

[51] Thoms, O.; Jamer, R. \& Paris, R. 2008, "The Effects of Transitional Justice Mechanisms", Center for International Policy Studies, CIPS Working Paper, retrieved from

http://www.humansecuritygateway.com/documents/CIPS Transitional Justice April2008.pdf [October 26, 2010]

[52] Torrance J. A. 2006, "The Theological Grounds for Advocating Forgiveness and Reconciliation in the Sociopolitical Realm", in The Politics of Past Evil. Religion, Reconciliation, and the Dilemmas of Transitional Justice, ed. D. Philpott, University of Notre Dame Press, Notre Dame, pp. 45-86.

[53] Snyder, J. \& Vinjamuri, L. 2003: "Trials and Errors. Principle and Pragmatism in Strategies of International Justice", International Security, vol. 28, no.3, pp. 544.

[54] Vinjamuri, L. \& Boesenecker P. A. 2007, "Accountability and Peace Agreements. Mapping the trends from 1980 to 2006", Centre for Humanitarian Dialogue, Geneva, retrieved from http://www.reliefweb.int/rw/lib.nsf/db900sid/EVOD77MERJ/\$file/Full Report.pdf?openelement [October 26, 2010].

[55] Wagatsuma, H. \& Rosett, A. 1986, "The Implications of Apology: Law and Culture in Japan and the United States", Law and Society Review, vol. 20, no. 4, pp. 461-498.

[56] Watts, R. 2002, 'Federalism Today. The Relevance Today of the Federal Idea', International Conference on Federalism, Saint Gallen, Switzerland. Also available at: http://www.forumfed.org/en/federalism/federalismtoday.php 